\title{
SEEDER-FERTILIZER MACHINE: ENERGETIC DEMAND AS A FUNCTION OF VEGETAL COVERING HANDLING AND MANURE DEPOSITION SHANK DEPTH IN NO-TILLAGE SYSTEM
}

\author{
DANILO C. C. GROTTA ${ }^{1}$, CARLOS E. A. FURLANI ${ }^{2}$, ROUVERSON P. DA SILVA ${ }^{3}$, \\ AFONSO LOPES ${ }^{4}$, GUSTAVO N. DOS REIS ${ }^{5}$
}

\begin{abstract}
The purpose of this work was evaluating the energetic demand of a seeder-fertilizer machine as a function of the type and handling of vegetal covering culture and of the fertilizer deposition shank depth. A Valtra BM100 tractor was used implemented to pull a high precision seeder-fertilizer machine with four ranks of seeding, spaced $0.9 \mathrm{~m}$ for maize culture. Experiment was conducted with design in randomized blocks in factorial plots, in the Laboratory of Machines and Agricultural Mechanization experimental area (LAMMA) of UNESP-Jaboticabal, using two covering cultures (black-mucuna and crotalaria), three handlings of this covering, two mechanical (straw crusher and roller knife) and one chemical (pulverization of herbicide), performed 120 days after seeding of covering cultures and three depths of fertilizer deposition shank, completing 18 treatments, with four repetitions, totaling 72 observations. Parameters of displacement speed, gliding, force on traction bar, peak force, power on pulling bar and fuel consumption were evaluated. It was possible to conclude that force on traction bar was less for depths of 0.11 and $0.14 \mathrm{~m}$ of fertilizer plough shank, the same occurring for peak force, power on traction bar and volumetric consumption. The specific consumption was lower at a depth of $0.17 \mathrm{~m}$ of fertilizer plough shank. Covering cultures and their handlings did not interfere in the performance of machines under inquiry.
\end{abstract}

KEYWORDS: fuel consumption, knife roller, traction force.

\section{SEMEADORA-ADUBADORA: DEMANDA ENERGÉTICA EM FUNÇÃO DO MANEJO DA COBERTURA VEGETAL E DA PROFUNDIDADE DA HASTE DE DEPOSIÇÃO DE ADUBO EM SISTEMA PLANTIO DIRETO}

RESUMO: O trabalho teve por objetivo avaliar a demanda energética de uma semeadoraadubadora, em função do tipo e manejo da cultura de cobertura vegetal e da profundidade da haste de deposição de adubo. Foi utilizado um trator Valtra BM100, instrumentado, para tracionar uma semeadora-adubadora de precisão equipada com quatro fileiras de semeadura espaçadas de $0,9 \mathrm{~m}$ para cultura de milho. O experimento foi conduzido em parcelas subsubdivididas, na área experimental do Laboratório de Máquinas e Mecanização Agrícola (LAMMA) da UNESPJaboticabal, utilizando duas culturas de cobertura (mucuna-preta e crotalária), três manejos dessas coberturas, sendo dois mecânicos (triturador de palhas e rolo-faca) e um químico (pulverização com herbicida), realizados 120 dias após a semeadura das culturas de cobertura e três profundidades da haste de deposição do adubo $(0,11 ; 0,14$ e $0,17 \mathrm{~m})$, perfazendo 18 tratamentos, com quatro repetições, totalizando 72 observações. Foram avaliados os parâmetros velocidade de deslocamento, patinagem, força na barra de tração, força de pico, potência na barra de tração, potência de pico e consumo de combustível. Pôde-se concluir que a força na barra de tração foi menor para as profundidades de 0,11 e 0,14 $\mathrm{m}$ da haste sulcadora de adubo, o mesmo ocorrendo para força de pico, potência na barra de tração e consumo volumétrico. O consumo específico foi menor na profundidade de $0,17 \mathrm{~m}$ da haste sulcadora de adubo. As culturas de cobertura e seus manejos não interferiram no desempenho das máquinas estudadas.

PALAVRAS-CHAVE: consumo de combustível, rolo-facas, força de tração.

\footnotetext{
${ }^{1}$ Eng ${ }^{0}$ Agrônomo, Prof. Dr., UNIFEB, Barretos - SP, dcgrotta@yahoo.com.br

${ }^{2}$ Eng $^{\mathbf{0}}$ Agrônomo, Prof. Assistant, Departamento de Engenharia Rural, UNESP, Jaboticabal - SP.

${ }^{3}$ Eng $^{\mathrm{O}}$ Agrícola, Prof. Dr., Departamento de Engenharia Rural, UNESP, Jaboticabal - SP.

${ }^{4}$ Eng ${ }^{\circ}$ Agrícola, Prof. Assistant, Departamento de Engenharia Rural, UNESP, Jaboticabal - SP.

${ }^{5}$ Eng ${ }^{0}$ Agrônomo, Post-Graduating, Departamento de Engenharia Rural, UNESP, Jaboticabal - SP.

Received by Editorial Board on October 16, 2007

Approved by Editorial Board on July 6, 2008
} 


\section{INTRODUCTION}

According to CARDOSO (1998), the no-tillage together with other procedures, is also arisen to minimize erosion, controlling rain water surface flowing by means of residues, which reduce velocity, remaining more time for its infiltration. CALEGARI (2004) quotes residues contribute to soil structuring through their better aggregation and higher aeration, favoring the growing of the later culture roots.

According to MERTEN \& FERNANDES (1998), no-tillage depends from biomass made up of harvest residues, green manures or weeds. Vegetal covering must remain on soil surface and weeds are controlled using herbicides, what suggests the gradual replacement of mechanicalchemical procedures (conventional preparation) by means of biological-cultural procedures (SPDD) of soil handling and a higher economical efficiency coming from the reduction of the inputs costs (MUZILLI, 1985; DERPSCH et al., 1991 and MUZILLI et al., 1997).

Vegetal covers can be handled by means of different equipments for this purpose, however, each one can influence directly the decomposition velocity of straw, due to a lower or higher material fragmentation (GAMERO et al., 1997). PRADO et al. (2002) except that, for no-tillage, the more recommended equipments for culture covering or green manure handling are knife roller, reapers and tractorized straw mowers.

Seed drilling-manure operations are of primary importance for the establishment of crop producer yearly cultures. In conservationist systems, such as no-tillage, soil and covering conditions are, generally, less favorable to seed and manure deposition, than those verified in strong mobilization preparations, and a greater care during this operation shall be necessary. Seed drillingmanure machines, beyond their fitting to different species, cultures, depths and spacing, shall be strong and resistant, have cutting discs for fodder and plough breakers, capable to cut vegetation and other culture rests out, deposing seeds at uniform depth, covering and compacting soil around them (PORTELLA et al., 1993 e DERPSCH et al., 1991).

Another no-tillage peculiarity is the machine behavior, as soil exhibits different properties from those found in conventional system, among them: density, resistance to implements cutting and covering presence, which could interfere on fuel consumption, traction force and power required. So, machine configuration changes, such as, for instance, the fertilizer plough shank depth of seeder-fertilizer machine, can possibly cause different reactions in its behavior. When evaluating the required energy demand for a seeder-fertilizer machine for no-tillage with nine seeding ranks, spaced $0.45 \mathrm{~m}$, under three conditions of soil covering, (spontaneous vegetation, dried oak grass and dried + rolled oak grass) and four displacement velocities for soy culture seeding. BORTOLOTTO et al. (2006) found an average traction force per seeding row of $24.04 \mathrm{kN}$, average gliding of $10.91 \%$, a volumetric consumption of $14.41 \mathrm{~L} \mathrm{~h}^{-1}$, an operating consumption of 6.00 $\mathrm{L} \mathrm{ha}^{-1}$, an average power on the bar of $35.52 \mathrm{~kW}$ and an operating power of $14.80 \mathrm{~kW} \mathrm{ha} \mathrm{h}{ }^{-1}$, for a tractor with a $77 \mathrm{~kW}(102.7 \mathrm{HP})$ motor.

During maize seeding with different depths of plough shank, using a seeder-fertilizer machine with six lines, spaced $0.45 \mathrm{~m}$, SILVA (2003) verified, hourly fuel consumption, mobilized area soil and traction force demand increased significantly with the increase of the shank working depth.

MARQUES et al. (1999), when comparing different handling methods of spontaneous vegetation, concluded, regarding to fuel consumption and time, herbicide handling exhibited the best results, as it showed the greatest working range width $(12 \mathrm{~m})$, in comparison with roller knife $(2 \mathrm{~m})$, reaper $(1.50 \mathrm{~m})$ and straw crusher $(2.30 \mathrm{~m})$. However, authors comment, the use of these mechanical handling equipments in planting area promote soil covering homogeneization, favoring pulverization.

MELLO FILHO \& RICHETTI (1997) report maize culture is of distinguished importance at national extent, under the socio-economic aspect, distinguishing itself for its agronomic importance, due to its use in culture rotation system, mainly in agro-systems where soy is the predominant culture. These authors quoted maize appears as an economical alternative in culture rotation 
planting, with the no-tillage, because it produces high quantity of dry material, when related to the minimum necessary for maintaining the system of $5 \mathrm{t} \mathrm{ha}^{-1}$, and it has a slow decomposition due to its high carbon/nitrogen ratio, which results in a good soil protection for a longer time period, and a dependence relation occurs between the no-tillage and the maize culture, also due to the quantity of residues produced, according to FANCELLI (2002).

This work had the purpose to evaluate the energetic demand of a seeder-fertilizer machine, as a function of the type and handling of vegetal covering culture and the depth of fertilizer deposition shank.

\section{MATERIAL AND METHODS}

Experiment was installed in the Machines and Agricultural Mechanization Laboratory (LAMMA) area of the Rural Engineering Department, UNESP-Jaboticabal - SP, Brazil, localized at the geographical coordinates $21^{\circ} 14^{\prime}$ 'south and $48^{\circ} 16^{\prime}$ west, with average altitude of $559 \mathrm{~m}$, exhibiting a Cwa climate (subtropical), according to Köeppen classification, in soil with $51 \%$ argil, $29 \%$ silt and $20 \%$ sand, which, during test, exhibited humidity of 24.3 and $26.5 \%$ for layers of 0 0.10 and $0.11-0.20 \mathrm{~m}$, respectively, $73 \%$ of vegetal covering, obtained by means of the methodology of LAFLEN et al. (1981), and penetration resistance of 1.7 and $3.3 \mathrm{MPa}$, in the layers of 0 to 0.10 and 0.11 to $0.20 \mathrm{~m}$, respectively.

The area where this work has been carried out is under direct planting since 2000, and every year vegetal covering formation cultures, with sequences of harvest maize and soy are planted therein, during the period between two harvests. In March 2004 crotalaria (Crotalaria juncea L.) and grey-mucuna (Stilozobium niveum L.) cultures were seeded, for fodder formation, and in November 2004, the same was made with maize (Zea mays L.) culture, which was followed up during this experiment.

Experimental parts were likewise handled since 2001, with three handling systems: two mechanical (straw mower (TR) and roller knife (RF)) and one chemical (herbicide applied with tractorized bar pulverizer (HE)).

Each experimental portion filled a $100 \mathrm{~m}^{2}(25 \times 4.0 \mathrm{~m})$ area and, among parts, in the longitudinal sense, a $15 \mathrm{~m}$ zone was reserved, with the purpose to carry out maneuvers, machines and equipments traffic, and to stabilize every treatment determinations.

Experimental outline was conducted in portions, subdivided in 18 experiments and four repetitions, totalling 72 observations, with two types of vegetal covering, grey-mucuna and crotalaria (main treatment), three kinds of covering culture handling, two mechanical (tractorized straw crusher and roller knife) and a chemical (herbicide application with pulverizer), as a secondary treatment, and three fertilizer deposition shank depths $(0.11 ; 0.14$ e $0.17 \mathrm{~m})$, as a tertiary treatment.

A Valtra ${ }^{\circledR}$ tractor was used, BM 100 model, 4x2 FWAD, with $73.6 \mathrm{~kW}(98 \mathrm{hp})$ when motor at $2.000 \mathrm{rpm}$. For maize culture seeding, a high precision seeder-fertilizer machine was used, of Marchesan/Tatu ${ }^{\circledR}$ trade mark, COP Suprema model, with seed doser device of pneumatic type, with four seeding rows, $0.90 \mathrm{~m}$ spaced. For vegetal covering handling, a straw crusher of Jumil ${ }^{\circledR}$ trade mark was used, JM TR-E 2500 model, with 40 knives, $2.3 \mathrm{~m}$ cutting width and with a mass of $800 \mathrm{~kg}$; roller knife mass of $1,370 \mathrm{~kg}, 0.92 \mathrm{~m}$ diameter, $1.63 \mathrm{~m}$ cutting width, with $16 \mathrm{knives}, 18 \mathrm{~cm}$ spaced; Jacto ${ }^{\circledR}$ trade mark pulverizer, S12/75 model, assembled, a tank of 600 L capacity, and a 12 $\mathrm{m}$ bar with 24 fan type beaks for herbicide application.

For real displacement velocity measuring, radar was used, localized on the right side of tractor, type RVS II, adopting real displacement velocity obtained with radar unit, when tractor was pulling seeder-fertilizer machine through pulling bar. For productivity measuring, ears from plants inserted through $4 \mathrm{~m}$ of central lines of each portion were collected, weighing grains by means of a digital electronic balance, with grain mass correction made to $13 \%$ humidity. Average force on 
traction bar was obtained through a M. SHIMIZU ${ }^{\circledR}$ load cell, TF400 model, with $100 \mathrm{kN}$ capacity, coupled between tractor pulling bar and seed drilling-manure machine. Load cell was connected to a data acquisition system, to obtain average traction force in a direct way.

Average power on traction bar was determined indirectly, using equation (1) as follows:

$$
\mathrm{PB}=\mathrm{Ft} \mathrm{v}
$$

where,

$\mathrm{PB}$ - power on traction bar, $\mathrm{kW}$;

FT - average traction force on bar, $\mathrm{kN}$, and

$\mathrm{v}$ - real displacement velocity, $\mathrm{m} \mathrm{s}^{-1}$.

For fuel consumption measuring, a prototype was used, as described by LOPES et al. (2003). For volumetric consumption determination, eq.(2) was used, as follows:

$$
\mathrm{Ch}=\frac{\mathrm{C} 3,6}{\mathrm{t}}
$$

where,

Ch - hourly consumption, $\mathrm{L} \mathrm{h}^{-1}$;

$\mathrm{C}$ - volume consumption, $\mathrm{mL}$;

$\mathrm{t}$ - trajectory elapsed time on portion, $\mathrm{s}$, and

3.6 - conversion factor.

For specific consumption calculation, following equation was used:

$$
\mathrm{CE}=\frac{\mathrm{DCh}}{\mathrm{PB}}
$$

where,

$\mathrm{CE}$ - specific consumption, $\mathrm{g} \mathrm{kW} \mathrm{h}^{-1}$;

D - fuel density $\left(\mathrm{g} \mathrm{L}^{-1}\right)$, according to GROTTA (2003);

$\mathrm{Ch}$ - hourly fuel consumption, $\mathrm{L} \mathrm{h}^{-1}$, and

$\mathrm{PB}$ - power on traction bar, $\mathrm{kW}$.

All quoted sensors (gliding, load cell, fluxometers, thermometers and radar) sent signals to data acquisition and storage system type micrologger CR23X, CAMPBELL SCIENTIFIC, INC trademark.

\section{RESULTS AND DISCUSSION}

According to Table 1 data, it can be observed that, for displacement velocity, only manure deposition depth factor exhibited a significant effect. It can be noted also that, covering culture factor and handling factor alone did not have any influence on this variable, similarly to what was found by BRANQUINHO et al. (2004). This result can be considered as a normal one, because, for higher working depths of plough shanks, higher tractorial constraints occur, so reducing displacement velocity of the whole.

From Table 1, it can be observed, for every covering handling, no significant difference existed for displacement velocity variable, and data obtained were in accordance with SILVEIRA et al. (2005) and FURLANI (2005), who also did not observe any statistical difference for this variable, when applying the same treatments, what points out a pulling efficiency similar to treatments.

For the factor fertilizer deposition depth a statistical difference occurred between $0.11 \mathrm{~m}$ depth and 0.14 and $0.17 \mathrm{~m}$ depth, which appeared to be similar, the displacement velocity variable exhibited a smaller value for the highest manure deposition shank depth, what was explained by the 
greater necessity of the required power, due to the constraint caused by the higher working depth of the fertilizer plough shanks.

For productivity variable, no significant differences were found between the inquired factors, showing that, independently from covering culture, handling method of covering cultures and fertilizer deposition depth, the same maintained itself similar, with an average of $8,800 \mathrm{~kg} \mathrm{ha}^{-1}$.

TABLE 1. Summary of variance analysis and test of averages for variables average velocity, $\left(\mathrm{km} \mathrm{h}^{1}\right)$, productivity $\left(\mathrm{kg} \mathrm{ha}^{-1}\right)$, average pulling force on bar $(\mathrm{kN})$ and peak force $(\mathrm{kN})$.

\begin{tabular}{|c|c|c|c|c|}
\hline Factors & $\begin{array}{l}\text { Average Velocity } \\
\qquad\left(\mathrm{km} \mathrm{h}^{-1}\right)\end{array}$ & $\begin{array}{l}\text { Productivity } \\
\left(\mathrm{kg} \mathrm{ha}^{-1}\right)\end{array}$ & $\begin{array}{c}\text { Average Force on } \\
\text { Pulling Bar } \\
(\mathrm{kN})\end{array}$ & Peak Force $(\mathrm{kN})$ \\
\hline \multicolumn{5}{|l|}{ Culture (C) } \\
\hline Mucuna & 4.1 & $8,616.7$ & 17.6 & 20.7 \\
\hline Crotalaria & 4.1 & $8,966.0$ & 16.7 & 20.1 \\
\hline C.V.\% & 1.9 & 23.3 & 19.7 & 22.3 \\
\hline DMS & 0.06 & $1,537.0$ & 2.5 & 3.4 \\
\hline \multicolumn{5}{|l|}{ Handling (M) } \\
\hline Roller Knife & 4.1 & $8,565.4$ & 17.1 & 20.1 \\
\hline Herbicide & 4.1 & $9,102.9$ & 16.9 & 20.5 \\
\hline Straw mower & 4.1 & $8,705.7$ & 17.4 & 20.6 \\
\hline C.V.\% & 1.2 & 12.7 & 8.2 & 11.8 \\
\hline DMS & 0.04 & 861.6 & 1.1 & 1.9 \\
\hline \multicolumn{5}{|l|}{$\overline{\text { Depth (P) }}$} \\
\hline $11 \mathrm{~cm}$ & $4.2 \mathrm{a}$ & $8,706.0$ & $16.0 \mathrm{a}$ & $19.0 \mathrm{a}$ \\
\hline $14 \mathrm{~cm}$ & $4.1 \mathrm{~b}$ & $8,901.7$ & $17.4 \mathrm{~b}$ & $20.6 \mathrm{~b}$ \\
\hline $17 \mathrm{~cm}$ & $4.1 \mathrm{~b}$ & 8,766.3 & $18.0 \mathrm{~b}$ & $21.5 \mathrm{~b}$ \\
\hline C.V.\% & 1.3 & 13.8 & 6.9 & 10.2 \\
\hline DMS & 0.04 & 856.2 & 0.8 & 1.5 \\
\hline \multicolumn{5}{|l|}{ test F } \\
\hline $\mathrm{C}$ & $0.56^{\mathrm{NS}}$ & $0.52^{\mathrm{NS}}$ & $1.17^{\mathrm{NS}}$ & $0.34^{\mathrm{NS}}$ \\
\hline M & $1.66^{\mathrm{NS}}$ & $1.49^{\mathrm{NS}}$ & $0.63^{\mathrm{NS}}$ & $0.28^{\mathrm{NS}}$ \\
\hline $\mathrm{P}$ & $21.24 * *$ & $0.16^{\mathrm{NS}}$ & $17.85 * *$ & $9.09 * *$ \\
\hline $\mathrm{C} \times \mathrm{M}$ & $0.35^{\mathrm{NS}}$ & $0.28^{\mathrm{NS}}$ & $0.20^{\mathrm{NS}}$ & $1.01 \mathrm{NS}$ \\
\hline $\mathrm{C} \times \mathrm{P}$ & $0.49^{\mathrm{NS}}$ & $0.78^{\mathrm{NS}}$ & $0.08^{\mathrm{NS}}$ & $1.90^{\mathrm{NS}}$ \\
\hline $\mathrm{M} \times \mathrm{P}$ & $0.25^{\mathrm{NS}}$ & $0.46^{\mathrm{NS}}$ & $0.51^{\mathrm{NS}}$ & $1.48^{\mathrm{NS}}$ \\
\hline $\mathrm{C} \times \mathrm{M} \times \mathrm{P}$ & $1.61^{\mathrm{NS}}$ & $0.45^{\mathrm{NS}}$ & $1.00^{\mathrm{NS}}$ & $0.74^{\mathrm{NS}}$ \\
\hline
\end{tabular}

In every column, for every factor, averages followed by the same small letter do not differ among themselves, through Tukey test, at $5 \%$ of probability. NS - not significant $(\mathrm{P}>0.05) ;{ }^{*}-\operatorname{significant}(\mathrm{P}<0.05)$; ** - significant $(\mathrm{P}<0.01)$; C.V. variation coefficient.

The behavior of the fertilizer deposition shank depth factor was the same; for highest depths used $(0.14$ and $0.17 \mathrm{~m})$, necessary force demands were statistically greater, when related to the lowest depth $(0.11 \mathrm{~m})$. This was also observed by SILVEIRA et al. (2005) and it is due to the greater tractorial constraint caused by seeder-fertilizer machine, when working at higher depths, and traction force values found were suitable for the seeder-fertilizer machine under evaluation.

In Table 1 it can be observed no interaction occurred, for both variables, among culture, handling and depth factors, and culture and handling factors did not influence, alone, forces under evaluation; for depth factor a different behavior was observed, which influenced alone, every variable, as quoted above, in agreement with results found by LEVIEN et al. (2000).

For the bar power variable (Table 2), at the lowest depths used $(0.14$ and $0.17 \mathrm{~m})$, demands were higher, when related to lowest depth $(0.11 \mathrm{~m})$, what was also observed by SILVEIRA et al. 
(2005), due to the same fact as previously mentioned for force variables. For peak power variable, value exhibited for lower depth $(0.11 \mathrm{~m})$ was statistically smaller than the value exhibited by higher depth $(0.17 \mathrm{~m})$, and intermediate depth $(0.14 \mathrm{~m})$ was not different from the two previous values.

Observing Table 2, it is possible to perceive, for these variables, culture, handling and depth factors did not exhibit any significant interaction between themselves, and culture and depth factors did not interfere alone on those variables. It was evidenced, depth factor influenced alone consumptions.

TABLE 2. Summary of variance analysis and average test for variables of average power $(\mathrm{kW})$, peak power $(\mathrm{kW})$, volumetric consumption $\left(\mathrm{L} \mathrm{h}^{-1}\right)$ and specific consumption $\left.\mathrm{g} \mathrm{kW} \mathrm{h}^{-1}\right)$.

\begin{tabular}{|c|c|c|c|c|}
\hline Factor & Average Power & Peak Power & Vol.Consumption & S. Consumption \\
\hline \multicolumn{5}{|l|}{ Culture (C) } \\
\hline Mucuna & 20.2 & 23.9 & 12.2 & 506.7 \\
\hline Crotalaria & 19.4 & 23.3 & 12.0 & 517.6 \\
\hline C.V.\% & 16.9 & 20.5 & 10.2 & 7.0 \\
\hline DMS & 2.5 & 3.6 & 0.9 & 26.9 \\
\hline \multicolumn{5}{|l|}{ Handling(M) } \\
\hline Knife Roller & 19.8 & 23.4 & 12.1 & 512.4 \\
\hline Herbicide & 19.4 & 23.6 & 12.0 & 517.1 \\
\hline Straw Mower & 20.1 & 23.8 & 12.2 & 507.0 \\
\hline C.V.\% & 7.2 & 10.5 & 2.9 & 5.8 \\
\hline DMS & 1.1 & 1.9 & 0.3 & 22.9 \\
\hline \multicolumn{5}{|l|}{ Depth (P) } \\
\hline $11 \mathrm{~cm}$ & $18.6 \mathrm{a}$ & $22.3 \mathrm{a}$ & $11.7 \mathrm{a}$ & $523.6 \mathrm{a}$ \\
\hline $14 \mathrm{~cm}$ & $20.0 \mathrm{~b}$ & $23.7 \mathrm{ab}$ & $12.5 \mathrm{~b}$ & $520.8 \mathrm{a}$ \\
\hline $17 \mathrm{~cm}$ & $20.8 \mathrm{~b}$ & $24.9 \mathrm{~b}$ & $12.2 \mathrm{~b}$ & $492.0 \mathrm{~b}$ \\
\hline C.V.\% & 6.4 & 9.8 & 3.4 & 5.1 \\
\hline DMS & 0.9 & 1.6 & 0.3 & 18.4 \\
\hline \multicolumn{5}{|l|}{ Test F } \\
\hline $\mathrm{C}$ & $0.94^{\mathrm{NS}}$ & $0.27^{\mathrm{NS}}$ & $0.64^{\mathrm{NS}}$ & $1.66^{\mathrm{NS}}$ \\
\hline M & $1.33^{\mathrm{NS}}$ & $0.14^{\mathrm{NS}}$ & $1.34^{\mathrm{NS}}$ & $0.68^{\mathrm{NS}}$ \\
\hline $\mathrm{P}$ & $17.64 * *$ & $7.57 * *$ & $23.74 * *$ & $10.75 * *$ \\
\hline $\mathrm{C} \times \mathrm{M}$ & $0.12^{\mathrm{NS}}$ & $0.98^{\mathrm{NS}}$ & $0.25^{\mathrm{NS}}$ & $0.01^{\mathrm{NS}}$ \\
\hline $\mathrm{C} \times \mathrm{P}$ & $0.21^{\mathrm{NS}}$ & $2.00^{\mathrm{NS}}$ & $0.58^{\mathrm{NS}}$ & $1.01^{\mathrm{NS}}$ \\
\hline $\mathrm{M} \times \mathrm{P}$ & $0.36^{\mathrm{NS}}$ & $1.65^{\mathrm{NS}}$ & $0.41^{\mathrm{NS}}$ & $0.45^{\mathrm{NS}}$ \\
\hline $\mathrm{C} \times \mathrm{M} \times \mathrm{P}$ & $1.36^{\mathrm{NS}}$ & $0.75^{\mathrm{NS}}$ & $0.13^{\mathrm{NS}}$ & $1.82^{\mathrm{NS}}$ \\
\hline
\end{tabular}

In every column, for every factor, averages followed by the same small letter do not differ among themselves, through Tukey test, at $5 \%$ of probability. NS - not significant $(\mathrm{P}>0.05) ; *$ - significant $(\mathrm{P}<0.05) ; * *$ - significant $(\mathrm{P}<0.01)$; C.V. - variation coefficient.

For the volumetric consumption variable, the behavior of the fertilizer deposition shank depth factor exhibited, for the higher depths under inquire $(0.14$ and $0.17 \mathrm{~m})$, the highest values, which were statistically similar and different from those exhibited at lowest depth $(0.11 \mathrm{~m})$. This fact can be explained by the greater need of power required.

For the specific consumption variable, values exhibited at the highest depth $(0.17 \mathrm{~m})$ were statistically lower than those exhibited at lower depth $(6.4 \%$ for $0.11 \mathrm{~m}$ and $5.9 \%$ for $0.14 \mathrm{~m})$, and the latter was similar, according to Tukey test at 5\% probability. This inversion of the observed values is due to the fact that, at a highest depth, an increase of power on traction bar is observed, and this increase is proportionally greater than that observed for fuel volumetric consumption, so incurring in smaller values for this variable, as observed by GROTTA (2003). 
For all variables, exception made to productivity, the factor of fertilizer deposition shank depth exhibited a significant difference. This behavior comes from the fact that, with shank deepening, a higher resistance will be applied to tractor, generating greater values of average traction force, peak force, average power, peak power and volumetric consumption, what, as a consequence, will reduce its average displacement speed and specific consumption, as this one depends upon average power and speed, the required power increased more than volumetric consumption. So, only taking into account productivity, it can be concluded ideal depth for fertilizer plougher shank would be the lowest one, $0.11 \mathrm{~m}$, because, at this depth a lower tractor constraint will be required, as a consequence, a higher working capability will be obtained.

\section{CONCLUSIONS}

Average traction force and peak force were the smallest for the lowest depth of fertilizer plough; the same occurred for average power and volumetric consumption.

Peak power was higher for the highest depth of manure plough.

Displacement velocity was higher for the lowest depth of the fertilizer plough shank.

Specific consumption was higher for the lowest depth of fertilizer plough.

Productivity remained unchanged for every treatment evaluated.

\section{BIBLIOGRAPHY}

BORTOLOTTO, V.C.; PINHEIRO NETO, R.; BORTOLOTTO, M.C. Demanda energética de uma semeadora-adubadora para soja sob diferentes velocidades de deslocamento e coberturas do solo. Engenharia Agrícola, Jaboticabal, v.26, n.1, p.122-130, 2006.

BRANQUINHO, K.B.; FURLANI, C.E.A.; LOPES, A.; SILVA, R.P.; GROTTA, D.C.C.; BORSATTO, E.A. Desempenho de uma semeadora-adubadora direta, em função da velocidade de deslocamento e do tipo de manejo da biomassa da cultura de cobertura do solo. Engenharia Agrícola, Jaboticabal, v.24, n.2, p.374-380, 2004.

CALEGARI, A. Alternativas de culturas para rotação em plantio direto. Revista Plantio Direto, Passo Fundo, n.80, p.62-70, 2004.

CARDOSO, F. P. Plantio direto na palha. São Paulo: Manah, 1998. 21 p.

DERPSCH, R.; ROTH, C.H.; SIDIRAS, N.; KOPKE, U. Controle da erosão no Paraná, Brasil: Sistemas de cobertura do solo, plantio direto e preparo conservacionista. Eschborn: GTZ, 1991. 272 p.

EMBRAPA. EMPRESA BRASILEIRA DE PESQUISA AGROPECUÁRIA. Sistema brasileiro de classificação de solos. Rio de Janeiro, 1999. $412 \mathrm{p}$.

FANCELLI, A.L. Cultura do milho é fundamental na estabilidade do sistema plantio direto. Plantio Direto, Passo Fundo, n.67, p.10-12, 2002.

FURLANI, C.E.A. Sistemas de rotação e manejo de culturas de cobertura em plantio direto de soja e milho. 2005. 99 f. Tese (Livre-Docência) - Faculdade de Ciências Agrárias e Veterinárias, Universidade Estadual Paulista, Jaboticabal, 2005.

GAMERO, C.A.; SIQUEIRA, R.; LEVIEN, R.; SILVA, S.L. Decomposição da aveia-preta (Avena strigosa Schre.) manejada com rolo-faca e triturador de palhas. In: CONGRESSO BRASILEIRO DE ENGENHARIA AGRÍCOLA, 26., 1997, Campina Grande. Anais... Campina Grande: Sociedade Brasileira de Engenharia Agrícola, 1997. 1 CD-ROM.

GROTTA, D.C.C. Desempenho de um trator agrícola em operação de gradagem utilizando biodiesel etílico filtrado de óleo residual como combustível. 2003. 44 f. Dissertação (Mestrado em Ciência do Solo) - Faculdade de Ciências Agrárias e Veterinárias, Universidade Estadual Paulista, Jaboticabal, 2003. 
LAFLEN, J.M.; AMEMIYA, A.; HINTZ, E.A. Measuring crop residue cover. Soil water Conservation, Ankeny, v.36, n.6, p.341-9, 1981.

LEVIEN, R.; GAMERO, C.A.; FURLANI, C.E.A. Desempenho de uma semeadora-adubadora de fluxo contínuo, em semeadura de aveia preta (Avena strigosa L.), sob diferentes preparos do solo. In: CONGRESSO BRASILEIRO DE ENGENHARIA AGRÍCOLA, 29., 2000, Fortaleza. Anais... Fortaleza: Sociedade Brasileira de Engenharia Agrícola, 2000. 1 CD-ROM.

LOPES, A.; LANÇAS, K.P.; FURLANI, C.E.A.; NAGAOKA, A.K.; CASTRO NETO, P.; GROTTA, D.C.C. Consumo de combustível de um trator em função do tipo de pneu, da lastragem e da velocidade de trabalho. Revista Brasileira de Engenharia Agrícola e Ambiental. Campina Grande, v.7, n.2, p.375-9, 2003.

MARQUES, J.P.; LEVIEN, R.; BENEZ, S.H. Desempenho operacional de um escarificador em solo sob vegetação espontânea diferentemente manejada. In: CONGRESSO BRASILEIRO DE ENGENHARIA AGRÍCOLA, 28., 1999, Pelotas. Anais... Pelotas: Sociedade Brasileira de Engenharia Agrícola, 1999. 1 CD-ROM.

MELLO FILHO, G. A.; RICHETTI, A. Aspectos socioeconômicos da cultura do milho. In: Milho: informações técnicas. Dourados: Embrapa Agropecuária Oeste, 1997. p.13-38. (Circular Técnica, 5)

MERTEN, G.H.; FERNANDES, F.F. Manejo do solo e baixa aptidão. In: DAROLT, M.R. (Coord.). Plantio Direto: pequena propriedade sustentável. Londrina: IAPAR, 1998. p.1-17. (Circular, 101)

MUZILLI, O. O plantio direto no Brasil. In: FANCELLI, A.L.; TORRADO, P.V.; MACHADO, J. (Coord.). Atualização em plantio direto. Campinas: Fundação Cargill, 1985. p.3-16.

MUZILLI, O.; BORGES, G.O.; MIRANDA, M. A sustentabilidade agrícola e o plantio direto. In: PEIXOTO, R.T.G.; AHRENS, D.C.; SAMAHA, M.J. Plantio direto: o caminho para uma agricultura sustentável. Ponta Grossa: Instituto Agronômico do Paraná, 1997. p.48-9.

PORTELLA, J.A.; FAGANELLO, A.; SATTLER, A. Máquinas e implementos para plantio direto. In: EMBRAPA. Plantio direto no Brasil. Passo Fundo: Aldeia Norte, 1993. p.29-36.

PRADO, R.M.; NATALE, W.; FURLANI, C.E.A. Manejo mecanizado de atividades para a implantação de culturas. Jaboticabal: Sociedade Brasileira de Engenharia Agrícola, 2002. 99 p.

SILVA, P.R.A. Mecanismos sulcadores de semeadora-adubadora na cultura do milho (Zea mays L.) no sistema de plantio direto. 2003. 84 f. Dissertação (Mestrado em Energia da Agricultura) Faculdade de Ciências Agronômicas, Universidade Estadual Paulista, Botucatu, 2003.

SILVEIRA, J.C.M.; MODOLO, A.J.; SILVA, S.L.; GABRIEL FILHO, A. Força de tração e potência de uma semeadora em duas velocidades de deslocamento e duas profundidades de deposição de sementes. Revista Brasileira de Engenharia Agrícola e Ambiental, Campina Grande, v.9, n.1, p.125-8, 2005. 